\title{
Analisis Putusan Mahkamah Agung Nomor 501 K/ PDT.SUS-PHI/ 2016 Tentang Pemutusan Hubungan Kerja
}

\author{
Sonhaji \\ Fakultas Hukum, Universitas Diponegoro \\ Jl.Prof.Soedarto, SH Tembalang Semarang \\ sonhajibapak@gmail.com
}

\begin{abstract}
The purpose of this study is to know that the Certain Working Agreement on Oral Time is not allowed in the legislation, the Supreme Court judges consideration in deciding the case Number 501 K / Pdt.Sus-PHI / 2016 and the conformity of the decision with the law applicable in Indonesia. This study uses normative juridical method, which is analytical descriptive, with data collection method in the form of library study and supported by interview with judges. The results of the research show that First, the judge's decision is unfair to both parties litigation because the defendant is not punished to pay the wage of suspension (wage process) with emphasis on the consideration of unwritten PKWT so that by law become PKWTT. Second The process wage demands which are not accepted by the judge are contrary to the laws and regulations on employment and on the settlement of industrial relations disputes because the law requires that workers and employers continue to perform their obligations until the establishment of an Industrial Dispute Settlement Institution, including the obligation of employers to pay the wage of a suspension (wages process). So the Supreme Court Decision Number 501 K / Pdt.SusPHI / 2016 is less in accordance with the prevailing laws and regulations in Indonesia.
\end{abstract}

Keywords: Oral Employment Agreement, Termination Dispute, Employment

\begin{abstract}
Abstrak
Penelitian ini bertujuan untuk mengetahui bahwa Perjanjian Kerja Waktu Tertentu yang dilakukan secara lisan tidak diperbolehkan di dalam peraturan perundang-undangan, pertimbangan hakim Mahkamah Agung dalam memutus perkara Nomor 501 K/Pdt.SusPHI/2016 dan kesesuaian putusan tersebut dengan peraturan perundang-undangan yang berlaku di Indonesia. Penelitian ini menggunakan metode yuridis normatif, yang bersifat deskriptif analitis, dengan metode pengumpulan data berupa studi kepustakaan dan didukung dengan wawancara bersama hakim. Hasil penelitian menunjukan bahwa Pertama, Putusan hakim kurang adil untuk kedua belah pihak yang berperkara karena tergugat tidak dihukum untuk membayar upah skorsing (upah proses) dengan menitikberatkan pada pertimbangan PKWT tidak tertulis sehingga demi hukum menjadi PKWTT. Kedua Tuntutan upah proses yang tidak dikabulkan oleh hakim bertentangan dengan peraturan perundang-undangan tentang ketenagakerjaan dan tentang penyelesaian perselisihan hubungan industrial karena undang-undang memerintahkan pekerja dan pengusaha tetap menjalankan kewajibannya sampai ada penetapan Lembaga Penyelesaian Perselisihan Industrial, termasuk kewajiban pengusaha membayarkan upah skorsing (upah proses). Maka Putusan Mahkamah Agung Nomor 501 K/Pdt.Sus-PHI/2016 kurang sesuai dengan peraturan perundang-undangan yang berlaku di Indonesia.
\end{abstract}

Kata Kunci : Perjanjian Kerja Lisan, Perselisihan Pemutusan Hubungan Kerja, Ketenagakerjaan 


\section{A. Pendahuluan}

Indonesia sebagai negara berkembang tentu tidak terlepas dari rencana industrialisasi yang segala aspeknya akan ditekankan pada sektor industri. Pemerintah Indonesia berpendapat bahwa hanya dengan jalan industrialisasi, Indonesia dapat mengejar ketertinggalannya dari negara modern. Pada proyek industrialisasi tersebut, dikehendaki atau tidak pasti akan timbul suatu strata dalam industri yaitu kedudukan pengusaha dan pekerja. Pengusaha dan pekerja mempunyai hubungan yang sangat erat karena jika tidak ada pengusaha maka tidak ada pekerja, begitu pula sebaliknya. Hubungan ini lalu diikatkan dalam suatu perjanjian, yaitu perjanjian kerja.

Pada Pasal 1601 a KUH Perdata disebutkan bahwa, "perjanjian kerja adalah suatu perjanjian dimana pihak kesatu (si buruh) mengikatkan dirinya untuk dibawah perintah pihak yang lain, si majikan untuk selama waktu tertentu melakukan pekerjaan dengan menerima upah.”, sedangkan pada Pasal 1 angka 14 Undang-Undang Nomor 13 Tahun 2003 tentang Ketenagakerjaan (Undang-Undang Ketenagakerjaan) menyebutkan bahwa, "perjanjian kerja adalah perjanjian antara pekerja/ buruh dengan pengusaha atau pemberi kerja yang memuat syarat-syarat kerja, hak, dan kewajiban para pihak.”.

Perjanjian kerja merupakan suatu perbuatan hukum yang dilakukan oleh pengusaha dan pekerja/ buruh sebelum kesepakatan bekerja dimulai. Setelah menyepakati perjanjian kerja, maka secara langsung maupun tidak langsung menimbulkan hak dan kewajiban bagi kedua belah pihak dan telah mengikat masing-masing pihak. Namun dalam pelaksanaannya, hal ini seringkali tidak sejalan seperti yang diharapkan karena antara pengusaha dengan pekerja mempunyai dua kepentingan yang berbanding terbalik. Di satu sisi, pengusaha berkeinginan untuk terus memperoleh keuntungan yang meningkat. Keuntungan itu diperoleh di antaranya dengan menekan biaya produksi, termasuk di dalamnya upah pekerja. Di sisi lain, pekerja mempunyai keinginan untuk selalu meningkatkan kesejahteraan diri dan keluarganya. Hubungan industrial dikatakan berhasil apabila ada keseimbangan antara penyelarasan kepentingan pengusaha dengan kepentingan pekerja ${ }^{1}$, namun yang banyak terjadi adalah pengusaha ingin memperoleh keuntungan yang meningkat tetapi ia tidak

\footnotetext{
${ }^{1}$ Asri Wijayanti, Hukum Ketenagakerjaan Pasca Reformasi (Jakarta : Sinar Grafika, 2009), hlm 63.
} 
memperhatikan kesejahteraan pekerjanya, sehingga hal ini pun menimbulkan perselisihan hubungan industrial.

Masalah perselisihan hubungan industrial memang masalah yang sangat rawan terjadi gesekkan antara para pihak yaitu pengusaha dan pekerja karena hubungan para pihak bersifat sub ordinatif. Hubungan yang bersifat sub ordinatif menimbulkan batasan dalam pelaksanaan perjanjian karena para pihak selalu sebagai atasan dan bawahan. Pengusaha sebagai pihak yang lebih tinggi secara sosial-ekonomi memberikan perintah kepada pekerja atau buruh yang secara sosial-ekonomi mempunyai kedudukan yang lebih rendah untuk melakukan pekerjaan tertentu. Hal-hal inilah yang menimbulkan perselisihan hubungan industrial. Masalah perselisihan hubungan industrial ada empat macam, yaitu perselisihan hak, perselisihan kepentingan, perselisihan Pemutusan Hubungan Kerja (PHK), dan perselisihan antar serikat pekerja atau serikat buruh dalam satu perusahaan.

Masalah PHK selalu menarik untuk dikaji lebih mendalam karena persolan PHK sangat berpengaruh bagi kelangsungan hidup para pekerja dan pengusaha. PHK merupakan peristiwa yang tidak diharapkan terjadinya, khususnya bagi pekerja/ buruh karena hal tersebut akan memberikan dampak psycologis, economis-financiil bagi pekerja/ buruh dan keluarganya. ${ }^{2}$ Putusnya hubungan kerja bagi pekerja/ buruh merupakan permulaan dari segala pengakhiran. Pengakhiran dari mempunyai pekerjaan, pengakhiran membiayai keperluan hidup sehari-hari bagi dirinya dan keluarganya, pengakhiran kemampuan menyekolahkan anak-anak, dan sebagainya. ${ }^{3}$

Aturan soal PHK dan konsekuensi yang yang harus diterima oleh pekerja dan/ atau dilakukan oleh pengusaha sudah diatur oleh Undang-Undang Ketenagakerjaan dengan rinci, namun tetap saja persoalan PHK selalu menjadi perdebatan. Ada pekerja yang menganggap tidak pantas untuk di PHK, ada yang menganggap proses PHK yang dikenakan kepadanya tidak sesuai dengan prosedur, bahkan ada pelaku usaha yang telah melakukan PHK tetapi tidak mau membayar uang pesangon ataupun uang penggantian hak.

Persoalan PHK ini pun tidak hanya menjadi perdebatan biasa antara pekerja dan pengusaha didalam gudang atau di depan pekerja lain. Tak sedikit persoalan PHK yang kemudian masuk ke Pengadilan Hubungan Industrial (PHI) untuk memperoleh putusan

\footnotetext{
2 F.X. Djumialdji dan Wiwoho Soejono, Perjanjian Perburuhan dan Hubungan Perburuhan Pancasila (Jakarta : Bina Aksara, 1985), hlm 88.

3 Iman Soepomo, Hukum Perburuhan Bidang Hubungan Kerja (Jakarta : Djambatan, 1974), hlm 143.
} 
pengadilan. Salah satu masalah perselisihan PHK yang berhubungan dengan perjanjian kerja dan perkaranya masuk ke dalam pengadilan dapat dilihat dari kasus antara PT. Virgo Makmur Perkasa dengan empat orang pekerjanya.

PT. Virgo Makmur Perkasa adalah perusahaan yang memiliki kontrak kerja dengan PT. Bukit Asam (Persero) Tbk pada pekerjaan jasa pengadaan pompa air di lokasi penambangan batu bara milik PT. Bukit Asam di Tanjung Enim, Sumatera Selatan. 4 (empat) orang dipekerjakan oleh PT. Virgo Makmur Perkasa di lokasi penambangan batu bara milik PT. Bukit Asam.

Pada tanggal 18 November 2013, 4 pekerja tersebut menerima surat dari PT. Virgo Makmur Perkasa yang pada intinya memberi sanksi skorsing (diisitirahatkan) sampai batas waktu yang tidak ditentukan. Akan tetapi selama proses skorsing ini, PT. Virgo Makmur Perkasa tidak membayar upah beserta hak lainnya kepada para pekerja terhitung sejak bulan Januari 2014 sampai dengan November 2014.

Tanggal 18 Desember 2013, mereka menerima pemutusan hubungan kerja (PHK). Alasan pemutusan hubungan kerja yang dikemukakan oleh PT. Virgo Makmur Perkasa adalah berakhirnya masa perjanjian kerja waktu tertentu (PKWT).

Para pekerja menolak alasan pemutusan hubungan kerja karena mereka meyakini tidak pernah ada pernyataan bahwa mereka selaku pekerja diikat secara kontrak dan juga tidak pernah menandatangani PKWT. Mereka lalu mengajukan mediasi pada Dinas Tenaga Kerja dan Transmigrasi Kabupaten Muara Enim namun tidak mencapai kemufakatan. Karena pada mediasi tersebut tidak mencapai kemufakatan maka para pekerja mengajukan gugatan kepada Pengadilan Hubungan Industrial pada Pengadilan Negeri Palembang (PHI PN Palembang). Hakim PHI PN Palembang memutus PT. Virgo Makmur Perkasa untuk membayar uang pengakhiran hubungan kerja secara sekaligus kepada empat pekerjanya dan menolak gugatan upah skorsing, Baik penggugat maupun tergugat mengajukan upaya hukum kasasi pada Mahkamah Agung (MA) karena tidak puas dengan putusan hakim PHI PN Palembang dan gugatan tersebut telah diputus dengan putusan Nomor $501 \mathrm{~K} / \mathrm{Pdt}$.SusPHI/2016 dengan putusan PHI PN Palembang tidak salah dalam menerapkan hukum (MA menguatkan putusan PHI PN Palembang).

Berdasarkan uraian latar belakang tersebut, maka dapat dirumuskan permasalahan sebagai berikut: Pertama, apakah Perjanjian Kerja Waktu Tertentu yang dilakukan secara 
lisan diperbolehkan di dalam peraturan perundang-undangan? Kedua, Bagaimana pertimbangan hakim Mahkamah Agung dalam memutuskan perkara antara PT. Virgo Makmur Perkasa dengan empat orang pekerjanya berdasarkan putusan Mahkamah Agung Nomor 501 K/Pdt.Sus-PHI/2016? Ketiga, Apakah putusan hakim pada putusan Mahkamah Agung Nomor $501 \mathrm{~K} / \mathrm{Pdt}$.Sus-PHI/2016 telah sesuai dengan peraturan perundang-undangan yang berlaku di Indonesia?

\section{B. Pembahasan}

Kasus perselisihan hubungan industrial ini terjadi antara PT. Virgo Makmur Perkasa dengan 4 (empat) orang pekerjanya yaitu Defri Oktaverian, Tri Saputra, Yosep Saputra, dan Darul Kodni. PT. Virgo Makmur Perkasa adalah perusahaan yang memiliki kontrak kerja dengan PT. Bukit Asam (Persero) Tbk pada pekerjaan jasa pengadaan pompa air di lokasi penambangan batu bara milik PT. Bukit Asam di Tanjung Enim, Sumatera Selatan. 4 (empat) orang pekerja tersebut dipekerjakan oleh PT. Virgo Makmur Perkasa di lokasi penambangan batu bara milik PT. Bukit Asam. Defri Oktaverian, Tri Saputra, dan Yosep Saputra mulai bekerja pada tanggal 1 November 2011, sedangkan Darul Kodni mulai bekerja pada tanggal 1 Desember 2012.

Pada tanggal 18 November 2013, para pekerja menerima surat dari PT. Virgo Makmur Perkasa yang pada intinya memberi sanksi skorsing (diisitirahatkan) sampai batas waktu yang tidak ditentukan. Akan tetapi selama proses skorsing ini, PT. Virgo Makmur Perkasa tidak membayar upah beserta hak lainnya kepada para pekerja terhitung sejak bulan Januari 2014 sampai dengan November 2014.

Tanggal 18 Desember 2013, mereka menerima pemutusan hubungan kerja (PHK). Alasan pemutusan hubungan kerja yang dikemukakan oleh PT. Virgo Makmur Perkasa adalah berakhirnya masa perjanjian kerja waktu tertentu (PKWT). Para pekerja menolak alasan pemutusan hubungan kerja karena mereka meyakini tidak pernah ada pernyataan bahwa mereka selaku pekerja diikat secara kontrak dan juga tidak pernah menandatangani PKWT.

Atas dasar hukum tersebut, para pekerja lalu mengajukan permohonan perundingan bipartit dan permohonan mediasi pada Dinas Tenaga Kerja dan Transmigrasi Kabupaten Muara Enim, oleh karena perundingan bipartit dan mediasi tersebut tidak mencapai kemufakatan, maka para pekerja mengajukan gugatan kepada Pengadilan Hubungan Industrial pada Pengadilan Negeri Palembang (PHI PN Palembang) dan melampirkan Risalah Penyelesaian Perselisihan 
Hubungan Industrial yang dikeluarkan oleh mediator hubungan industrial Dinas Ketenagakerjaan dan Transmigrasi Kabupaten Muara Enim. Terhadap gugatan tersebut PHI PN Palembang telah memberikan putusan Nomor 28/Pdt.Sus-PHI/2014/PN Plg. pada tanggal 8 April 2015.

\section{Perjanjian secara Lisan Mengubah Perjanjian Kerja Waktu Tertentu menjadi Perjanjian Kerja Waktu Tidak Tertentu}

Dalam konteks hukum perjanjian dikenal beberapa asas penting yang harus diperhatikan oleh para pihak yang membuat perjanjian, salah satunya adalah asas kekebasan berkontrak. Asas kebebasan berkontrak sebagaimana yang diatur dalam Pasal 1338 ayat (1) KUH Perdata. Makna kebebasan berkontrak ialah setiap orang bebas untuk menentukan dengan siapa ia akan membuat perjanjian, bebas untuk menentukan bentuk dan isi perjanjian dan bebas untuk membuat pilihan hukum (choice of law). Setiap orang pada dasarnya boleh membuat kontrak (perjanjian) yang berisi berbagai macam perjanjian asal tidak bertentangan dengan undang-undang, kesusilaan, dan ketertiban umum. ${ }^{4}$ Asas kebebasan berkontrak menunjukkan bahwa perlu adanya keseimbangan kedudukan antara pihak pembuatnya. Namun, dalam prakteknya asas ini sering kali mengalami ketidaksesuaian, contohnya pada perjanjian kerja.

Pada dasarnya tidak ada perbedaan antara perjanjian kerja dengan perjanjian pada umumnya mengenai syarat-syarat sahnya perjanjian. Dalam perjanjian kerja juga harus ada kesepakatan kedua belah pihak, kedua belah pihak harus cakap hukum, ada objek yang diperjanjikan (berupa pekerjaan), dan objek yang diperjanjikan tersebut tidak bertentangan dengan ketertiban umum, kesusilaan, dan peraturan perundang-undangan yang berlaku. Ketiadaan salah satu dari syarat-syarat tersebut tidak akan memungkinkan terbentuknya perjanjian.

Walaupun demikian, jika ditinjau dari asas keseimbangan para pihak dalam pembuatan perjanjian, konsep perjanjian kerja berbeda dengan konsep perjanjian pada umumnya yang bercirikan adanya keseimbangan para pihak. Dalam perjanjian kerja, kedudukan pekerja/ buruh selalu berada pada pihak yang lemah. Pengusaha mempunyai hak untuk menentukan prosedur yang perlu diikuti pekerja/ buruh dan cara melaksanakan kerja tersebut. Pekerja/ buruh tergantung kepada hubungan dengan pengusaha untuk mata pencaharian yang berkelanjutan dan juga untuk aspek-aspek penting pribadi pekerja/ buruh. Karena ketergantungannya ini, maka

\footnotetext{
${ }^{4}$ Abdul Khakim, Pengantar Hukum Ketenagakerjaan Indonesia : Berdasarkan Undang-Undang Nomor 13 Tahun 2003, (Bandung : PT. Citra Aditya Bakti, 2003), hlm 28.
} 
pengusaha mempunyai kekuatan dominan untuk mengendalikan pekerja/ buruh yang bekerja kepadanya.

Adanya ketidakseimbangan kedudukan para pihak dalam membentuk hubungan kerja, yakni kedudukan pekerja/ buruh yang selalu berada pada pihak yang lemah telah menjadikan sebuah dasar bagi negara untuk mencampuri hubungan tersebut, yang bertujuan untuk keadilan dan perlindungan. Hal ini diwujudkan oleh negara dengan membuat peraturan perundangundangan bidang ketenagakerjaan yang harus dipatuhi oleh pengusaha dan pekerja/ buruh. Dengan demikian, undang-undang ketenagakerjaan mengatur bahwa adanya hubungan hukum yang disebabkan pembentukan perjanjian kerja haruslah tidak bertentangan dengan landasan hukum yang telah ditetapkan.

Hubungan hukum antara pengusaha dengan pekerja/ buruh sebagian besar terikat dengan peraturan perundang-undangan mengenai ketenagakerjaan. Dibentuknya peraturan perundangundangan bidang ketenagakerjaan membatasi ruang gerak kebebasan pengusaha dan pekerja/ buruh dalam menetapkan isi perjanjian kerja. Hal ini merupakan satu bentuk campur tangan negara dalam melindungi hak-hak dasar pekerja/ buruh dengan memperhatikan akibatnya terhadap kemajuan negara. Dengan wujud campur tangan negara, maka pelaksanaan asas kebebasan berkontrak antara pengusaha dan pekerja/ buruh dalam perjanjian kerja menjadi sangat terbatas.

Pada Pasal 1 angka (14) Undang-Undang Ketenagakerjaan, pengertian perjanjian kerja ialah "perjanjian antara pekerja/ buruh dan pengusaha yang memuat syarat-syarat kerja, hak, dan kewajiban kedua belah pihak."

Pasal 51 Undang-Undang Ketenagakerjaan menyebutkan bahwa perjanjian kerja dapat dibuat baik secara tertulis maupun secara lisan. Perjanjian kerja secara lisan sah selama tidak bertentangan dengan ketentuan Pasal 52 ayat (1) Undang-Undang Ketenagakerjaan, yakni:

a. Kesepakatan kedua belah pihak;

b. Kemampuan atau kecakapan melakukan perbuatan hukum;

c. Adanya pekerjaan yang diperjanjikan;

d. Pekerjaan yang diperjanjikan tidak bertentangan dengan ketertiban umum, kesusilaan, dan peraturan perundang-undangan yang berlaku.

Sebelum menentukan apakah perjanjian kerja tersebut akan dibuat secara tertulis atau lisan, harus ditinjau terlebih dahulu perjanjian kerja tersebut adalah Perjanjian Kerja Waktu 
Tertentu (PKWT) atau Perjanjian Kerja Waktu Tidak Tertentu (PKWTT), karena terhadap dua perjanjian kerja tersebut mempunyai hak dan kewajiban yang berbeda.

Pada dasarnya, perjanjian kerja tidak harus dilakukan secara tertulis. Akan tetapi, terdapat pengecualian dalam hal PKWT. Pasal 57 ayat (1) dan ayat (2) Undang-Undang Ketenagakerjaan mensyaratkan PKWT harus dilakukan secara tertulis serta harus menggunakan bahasa Indonesia dan huruf latin. Jika ternyata PKWT tersebut dibuat secara lisan, maka demi hukum perjanjian kerja tersebut menjadi PKWTT atau biasa diketahui dengan pekerja tetap. Dengan berubahnya status perjanjian kerja tersebut, maka pekerja/ buruh dapat menuntut hakhak sebagai pekerja/ buruh dengan status hubungan kerja PKWTT. Jadi, perjanjian kerja yang diperbolehkan untuk dibuat secara lisan hanyalah PKWTT.

Dalam hal perusahaan tidak membuat PKWTT secara tertulis dengan pekerjanya, maka pengusaha wajib membuat surat pengangkatan bagi pekerja/ buruh yang bersangkutan, hal ini diatur pada Pasal 63 Undang-Undang Ketenagakerjaan. Surat pengangkatan tersebut sekurangkurangnya memuat keterangan:

a. Nama dan alamat pekerja/ buruh;

b. Tanggal mulai bekerja;

c. Jenis pekerjaan; dan

d. Besarnya upah.

Pada permasalahan yang telah telah diputus dengan putusan Mahkamah Agung Nomor 501 K/Pdt.Sus-PHI/2016 tersebut, para pekerja yaitu Defri Oktaverian, Tri Saputra, Yosep Saputra, dan Darul Kodni bekerja di PT. Virgo Makmur Perkasa dengan tidak pernah ada pernyataan bahwa mereka selaku pekerja diikat secara kontrak dan juga tidak pernah menandatangani PKWT. Pasal 57 ayat (2) Undang-Undang Ketengakerjaan mengatur PKWT yang dibuat tidak tertulis bertentangan dengan ketentuan Pasal 57 ayat (1), maka, sejak awal para pekerja tersebut bekerja dinyatakan sebagai pekerja dengan perjanjian kerja waktu tidak tertentu (PKWTT). Dengan berubahnya status perjanjian kerja dari PKWT yang demi hukum menjadi PKWTT, maka para pekerja dapat menuntut hak-hak sebagai pekerja/ buruh dengan status hubungan pekerja tetap, termasuk mendapatkan pesangon, uang penggantian hak, dan upah skorsing ketika mereka di-PHK. 
2. Pertimbangan Hakim Mahkamah Agung dalam Memutuskan Perkara antara PT. Virgo Makmur Perkasa dengan Empat Orang Pekerjanya berdasarkan Putusan Mahkamah Agung Nomor 501 K/ Pdt.Sus-PHI/ 2016

Sebelum memberikan putusan pada perselisihan hubungan industrial, hakim akan membuat pertimbangan hukum terlebih dahulu. Pertimbangan hukum yang diberikan oleh Majelis Hakim dalam memutuskan suatu perkara sangat penting karena pertimbangan hukum tersebut merupakan dasar dan bagian dari putusan itu sendiri. Pertimbangan-pertimbangan hukum dilakukan terhadap tiap-tiap bagian perkara dengan tujuan agar putusan yang dihasilkan mempunyai nilai keobjektifan.

Fakta hukum yang didapatkan oleh hakim yaitu Defri Oktaverian, Tri Saputra, dan Yosep Saputra telah bekerja pada PT. Virgo Makmur Perkasa selama 2 tahun 2 bulan serta Darul Kodni telah bekerja selama 1 tahun 1 bulan dan mereka diikat dengan PKWT namun secara lisan. PT. Virgo Makmur Perkasa selaku tergugat memberikan surat skorsing pada tanggal 18 November 2013, setelah itu memberikan surat PHK pada tanggal 18 Desember 2013 kepada para pekerja selaku penggugat dengan alasan telah berakhirnya PKWT, padahal PKWT yang mereka perjanjikan menyalahi peraturan perundang-undangan yang berlaku dan demi hukum telah berubah menjadi PKWTT. Maka, sesuai dengan ketentuan Pasal 164 ayat (3) Undang-Undang Ketenagakerjaan, PT. Virgo Makmur Perkasa telah melakukan PHK tanpa alasan yang sah dan dapat dikategorikan perusahaan melakukan efissiensi (pengurangan karyawan), sehingga ada hak-hak normatif yang harus didapatkan pekerja/ buruh.

Menurut Undang-Undang Ketenagakerjaan Pasal 93 ayat (2) huruf f, pengusaha wajib membayar upah apabila PHK akibat kesalahan sendiri/ halangan dari pengusaha. Atas dasar tersebut maka para pekerja mengajukan permohonan perundingan bipartit dan mediasi pada Dinas Tenaga Kerja dan Transmigrasi Kabupaten Muara Enim. Namun karena perundingan bipartit dan mediasi tersebut tidak mencapai kemufakatan, penggugat melanjutkan perkara tersebut ke PHI PN Palembang.

Para pekerja PT. Virgo Makmur Perkasa menuntut agar majelis hakim PHI PN Palembang memutus pengusaha membayarkan upah skorsing pada putusan sela, uang pesangon dan uang penggantian hak dalam pokok perkara. Namun dalam putusan hakim PHI PN Palembang Nomor 28/Pdt.Sus-PHI/2014/PN.Plg hanya memutus uang pesangon dan uang penggantian hak, tidak memutus upah skorsing. Putusan tersebut pun telah dikuatkan dengan 
putusan Mahkamah Agung Nomor 501 K/Pdt.Sus-PHI/2016. Dalam pertimbangan hakim Mahkamah Agung, menurut kebiasaan dalam praktek peradilan, pada PKWT yang diputus menjadi PKWTT, pengusaha wajib membayar uang pesangon namun tanpa upah proses.

Pada dasarnya, hak pekerja/ buruh atas upah timbul pada saat terjadi hubungan kerja antara pekerja/ buruh dengan pengusaha dan berakhir pada saat putusnya hubungan kerja. Jadi, pekerja yang dikenakan skorsing oleh pengusaha tetap berhak menerima upah karena belum mendapatkan putusan dari lembaga penyelesaian perselisihan hubungan industrial yang berkekuatan hukum tetap. Selain ketentuan di atas, Pasal 93 ayat (1) juncto ayat (2) huruf $\mathrm{f}$ Undang-Undang Ketenagakerjaan juga telah mengatur yang pada intinya pengusaha tetap wajib membayar upah pekerja/ buruh yang bersedia melakukan pekerjaan yang diperjanjikan tetapi pengusaha tidak mempekerjakannya, baik karena kesalahan sendiri maupun halangan yang seharusnya dapat dihindari pengusaha. ${ }^{5}$ Maka atas dasar tersebut, seharusnya majelis hakim memberikan putusan sela. Putusan sela dijatuhkan sebelum memutus pokok perkara dan dimaksudkan untuk menghukum pengusaha agar membayar upah skorsing menuju PHK. Bila mengacu pada Pasal 96, pekerja/ buruh berhak atas upah skorsing bila pengusaha terbukti melakukan skorsing namun tidak membayar upah. ${ }^{6}$

Pasal 155 ayat (2) mengatur: "Selama putusan lembaga penyelesaian perselisihan hubungan industrial belum ditetapkan, baik pengusaha maupun pekerja/ buruh harus tetap melaksanakan segala kewajibannya." dan Pasal 155 ayat (3) mengatur: "Pengusaha dapat melakukan penyimpangan terhadap ketentuan sebagaimana dimaksud dalam ayat (2) berupa tindakan skorsing kepada pekerja/ buruh yang sedang dalam proses pemutusan hubungan kerja dengan tetap wajib membayar upah beserta hak-hak lainnya yang biasa diterima pekerja/buruh". Pasal 155 Undang-Undang Ketenagakerjaan memerintahkan pekerja dan pengusaha tetap menjalankan kewajibannya sampai ada penetapan Lembaga Penyelesaian Perselisihan Industrial, namun pengusaha diperkenankan melakukan skorsing terhadap pekerja dengan catatan tetap membayar upah pekerja.

Untuk menjalankan Pasal 155 Undang-Undang Ketenagakerjaan ini, hakim sebenarnya dapat menetapkan putusan sela yang memerintahkan membayar upah pekerja bila pengusaha

\footnotetext{
5 Tri Jata Ayu Pramesti, Bolehkah Memotong Upah Pekerja yang di-Skorsing?, http://www.hukumonline.com/klinik/detail/lt51480c37790ca/bolehkah-memotong-upah-pekerja-yang-di-skorsing, diakses pada tanggal 19 Januari 2018.

6 Konfederasi Serikat Buruh Sejahtera Indonesia, Putusan Sela Pengadilan Hubungan Industrial, http://www.ksbsi.org/index.php/baca/lengkap/154, diakses pada tanggal 19 Januari 2018.
} 
tidak menjalankan kewajibannya sebagaimana diatur Pasal 96 Undang-Undang PPHI. Putusan sela sesuai Pasal 96 Undang-Undang PPHI hanya dapat dipakai bila pengusaha melakukan skorsing. Putusan PHI dinyatakan berkekuatan hukum tetap apabila memenuhi salah satu dari dua syarat berikut:

1. Salah satu pihak tidak mengajukan kasasi atas putusan PHI di tingkat pertama.

2. Hakim kasasi pada Mahkamah Agung telah memutus permohonan kasasi.

Berdasarkan dua syarat tersebut maka seharusnya PHI PN Palembang saat memutus perkara harus menghitung upah skorsing sampai pada putusan tersebut diucapkan. Selanjutnya, saat perselisihan diajukan kasasi, hakim Mahkamah Agung menghitung upah skorsing sampai putusan kasasi diucapkan. Dengan demikian, hakim dapat menghukum pengusaha membayar upah skorsing sampai putusan kasasi tersebut terucap. Hal ini sekaligus menegaskan bahwa pengertian dari "berkekuatan hukum tetap" pada Pasal 155 ayat (2) Undang-Undang Ketenagakerjaan adalah sampai putusan tersebut inkracht dan tidak ada upaya hukum lagi. Sebab, apabila salah satu pihak atau para pihak mengajukan kasasi terhadap putusan PHI tingkat pertama maka "berkekuatan hukum tetap" itu ada pada putusan kasasi.

Hal ini juga dikuatkan dengan adanya putusan Mahkamah Konstitusi Nomor 37/PUUIX/2011 tentang Permohonan Pengujian Undang-Undang Nomor 13 Tahun 2003 tentang Ketenagakerjaan terhadap UUD NRI 1945, tanggal 19 September 2011, yang amar putusannya menyatakan:

“Frasa 'belum ditetapkan' dalam Pasal 155 ayat (2) Undang-Undang Nomor 13 Tahun 2003 tentang Ketengakerjaan bertentangan dengan UUD NRI 1945 dan tidak mempunyai kekuatan hukum mengikat sepanjang tidak dimaknai 'belum berkekuatan hukum tetap'."

Dengan putusan tersebut maka penafsiran Pasal 155 ayat (2) Undang-Undang Ketenagakerjaan mengenai anak kalimat "belum ditetapkan" harus dimaknai "belum berkekuatan hukum tetap". Jangka waktu pembayaran upah skorsing atau upah proses terhadap pekerja yang sedang dalam proses PHK tergantung apakah salah satu pihak atau para pihak mengajukan kasasi terhadap putusan PHI tingkat pertama. Jika salah satu pihak atau para pihak mengajukan kasasi maka "berkekuatan hukum tetap" itu ada pada putusan kasasi. Karena hakim PHI PN Palembang dan Mahkamah Agung seharusnya memutus upah skorsing namun tidak memutusnya, maka menurut penulis putusan Mahkamah Agung Nomor 501 K/Pdt.SusPHI/2016 tidak sesuai dengan peraturan perundang-undangan yang berlaku. 


\section{Perbandingan Pertimbangan Hakim dalam Putusan Mahkamah Agung Nomor 501 K/Pdt.Sus-PHI/2016 dengan Putusan Mahkamah Agung Nomor 404 K/Pdt.Sus- PHI/2014}

Permasalahan yang diputus dengan putusan Mahkamah Agung Nomor 501 K/Pdt.SusPHI/2016 dan Putusan Mahkamah Agung Nomor 404 K/Pdt.Sus-PHI/2014 adalah serupa. Pengusaha (tergugat) dari setiap putusan tersebut telah menyalahi aturan Undang-Undang Ketenagakerjaan mengenai PKWT.

Pada putusan Mahkamah Agung Nomor 501 K/Pdt.Sus-PHI/2016 yakni perkara antara PT. Virgo Makmur Perkasa dengan 4 (empat) orang pekerjanya, PKWT yang dilakukan pengusaha demi hukum menjadi PKWTT karena pada Pasal 57 ayat (1) dan ayat (2) UndangUndang Ketenagakerjaan mengatur bahwa:

(1) Perjanjian kerja untuk waktu tertentu dibuat secara tertulis serta harus menggunakan bahasa Indonesia dan huruf latin.

(2) Perjanjian kerja untuk waktu tertentu yang dibuat tidak tertulis bertentangan dengan ketentuan sebagaimana dimaksud dalam ayat (1) dinyatakan sebagai perjanjian kerja untuk waktu tidak tertentu.

Pada permasalahan yang terjadi, para pekerja tersebut bekerja di PT. Virgo Makmur Perkasa tidak pernah ada pernyataan bahwa mereka selaku pekerja diikat secara kontrak dan juga tidak pernah menandatangani PKWT. Pasal 57 ayat (2) Undang-Undang Ketengakerjaan mengatur PKWT yang dibuat tidak tertulis bertentangan dengan ketentuan Pasal 57 ayat (1), maka, sejak awal bekerja para pekerja tersebut dinyatakan sebagai pekerja dengan perjanjian kerja waktu tidak tertentu (PKWTT). Selain itu, PKWT tersebut juga tidak memenuhi syarat PKWT sebagaimana dimaksud Pasal 59 ayat (1) dan ayat (2) Undang-Undang Ketenagakerjaan juncto Pasal 3, Pasal 4 dan Pasal 5 Kepmenakertrans Republik Indonesia Nomor 100/MEN/VI/2004 tentang Ketentuan Pelaksanaan Perjanjian Kerja Waktu Tertentu, hal ini disebabkan sifat, jenis dan kegiatan pekerjaan jasa pengadaan pompa pada aktivitas pertambangan batu bara di PT. Bukit Asam adalah terus menerus dan bersifat tetap, sehingga demi hukum hubungan kerja yang dimaksud menjadi PKWTT. Sedangkan pada kasus yang telah diputus dengan putusan Mahkamah Agung Nomor 404 K/Pdt.Sus-PHI/2014, Yuan Agusta (penggugat) bekerja pada Hotel Sahid Jaya Surakarta sejak tanggal 1 November 2001 sampai 
dengan tanggal 31 Mei 2013 (selama kurang lebih 11 tahun) dengan status kontrak atau Perjanjian Kerja Waktu Tertentu (PKWT). Selama Penggugat bekerja di Hotel Sahid Jaya Surakarta, ia telah berganti bagian 11 kali. Hal ini bertentangan dengan Pasal 59 UndangUndang Ketenagakerjaan karena jika dilihat dengan seksama, PKWT yang diberikan oleh Martono Saputra, General Manager Hotel Sahid (tergugat) kepada Yuan Agusta (penggugat), Tergugat memberikan kontrak kerja kepada Penggugat untuk paling lama 1 (satu) tahun, dan diperpanjang 2 (dua) sampai paling banyak 3 (tiga) kali. Kemudian Tergugat mengganti bagian pekerjaan Penggugat dan mengadakan kontrak baru lagi. Melihat dari fakta hukum ini, sudah tidak dapat dipungkiri bahwa pihak pemberi kerja tahu secara pasti bahwa status PKWT telah berubah menjadi PKWTT.

Selain PKWT yang diberikan kepada Yuan Agusta penggugat tidak hanya melebihi dari yang dipersyaratkan yaitu paling lama hanya 3 (tiga) tahun, setiap bagian yang selalu ditempatkan oleh Tergugat kepada Penggugat selama 11 (sebelas) tahun Penggugat bekerja adalah pada pekerjaan yang bersifat tetap, bukan pekerjaan yang bersifat musiman. Sehingga, berdasarkan Pasal 59 ayat (7) Undang-Undang Ketenagakerjaan, PKWT yang dibuat dengan tidak memenuhi Pasal 59 ayat (1), (2), (4), (5) dan (6), maka demi hukum PKWT tersebut dinyatakan batal demi hukum. Sebagai konsekuensi hukum dari batalnya PKWT Penggugat, maka sejak pertama kali Penggugat bekerja pada Tergugat yaitu pada tanggal 1 November 2001 dimana Penggugat bekerja pada bagian Restaurant Bar Cashier Hotel Sahid Jaya Surakarta adalah berstatus pegawai tetap.

Kedua putusan Mahkamah Agung diatas selain menuntut PKWT yang demi hukum menjadi PKWTT, juga menuntut agar Majelis Hakim memberikan putusan sela. Pada putusan Nomor 501 K/Pdt.Sus-PHI/2016, para penggugat meminta majelis hakim untuk menyatakan perbuatan Tergugat yang secara nyata tidak melaksanakan kewajiban membayar upah beserta hak-hak lainnya yang biasa diterima Para Pengugat selama skorsing terhitung sejak bulan Januari 2014 sampai dengan November 2014 adalah perbuatan melanggar hukum. Para Penggugat meminta hakim untuk menghukum Tergugat membayar secara tunai, upah beserta hak-hak lainnya yang biasa diterima Para Penggugat selama skorsing sebesar Rp100.760.000,00 (seratus juta tujuh ratus enam puluh ribu rupiah) paling lambat 7 (tujuh) hari setelah dibacakannya putusan sela tersebut, namun hakim menolak memberikan putusan sela. Pada putusan Nomor 404 K/Pdt.Sus-PHI/2014, Penggugat memuntut agar majelis hakim memutus 
Tergugat untuk membayarkan upah/ gaji (hak normatif) selama selama proses penyelesaian, yaitu upah mulai dari bulan Juni sampai dengan November 2013 (saat gugatan diajukan) sebesar Rp2.563.000,00 (dua juta lima ratus enam puluh tiga ribu rupiah) x $6=\mathrm{Rp} 15.361 .800,00$ (lima belas juta tiga ratus enam puluh satu ribu delapan ratus rupiah) kepada Penggugat. Namun, majelis hakim juga menolak untuk memberikan putusan sela yang menghukum tergugat untuk membayar upah proses kepada penggugat.

Dalam hal ini, menurut Sugianto, S.H., M.H. ${ }^{7}$ upah proses ada beberapa pandangan. Pertama, pandangan "no work no paid" yang artinya tidak ada pekerjaan maka tidak dibayar. Pandangan yang kedua adalah upah proses bisa disetujui, sepanjang PHK itu berlakunya surut. Pasal 155 ayat (2) Undang-Undang Ketenagakerjaan menyatakan: "Selama putusan lembaga penyelesaian perselisihan hubungan industrial belum ditetapkan, baik pengusaha maupun pekerja/ buruh harus tetap melaksanakan segala kewajibannya", maka seharusnya pengusaha melaksanakan pemberian upah proses kepada pekerja.

Pada amar putusan Mahkamah Konstitusi No 37/PUU-IX/2011 tentang Permohonan Pengujian Undang-Undang Nomor 13 Tahun 2003 tentang Ketenagakerjaan terhadap UUD NRI 1945, tanggal 19 September 2011 menyatakan: "Frasa 'belum ditetapkan' dalam Pasal 155 ayat (2) Undang-Undang Nomor 13 Tahun 2003 tentang Ketenagakerjaan bertentangan dengan UUD NRI 1945 dan tidak mempunyai kekuatan hukum mengikat sepanjang tidak dimaknai 'belum berkekuatan hukum tetap'."

Maka, berdasarkan fakta-fakta hukum dalam persidangan di atas, penulis berpendapat bahwa perkara yang telah diputus oleh Mahkamah Agung Nomor 501 K/Pdt.Sus-PHI/2016 dan Nomor 404 K/Pdt.Sus-PHI/2014 tidak sesuai dengan Undang-Undang Nomor 13 Tahun 2003 tentang Ketenagakerjaan dan Undang-Undang Nomor 2 Tahun 2004 tentang Penyelesaian Perselisihan Hubungan Industrial.

\section{Kesesuaian Putusan Mahkamah Agung Nomor 501 K/Pdt.Sus-PHI/2016 dengan Peraturan Perundang-Undangan yang Berlaku di Indonesia}

Perjanjian kerja merupakan salah satu jenis perjanjian. Syarat sahnya suatu perjanjian diatur dalam Pasal 1320 KUH Perdata, yakni sepakat mereka yang mengikatkan dirinya, kecakapan untuk membuat suatu perikatan, suatu hal tertentu, dan suatu sebab yang halal.

\footnotetext{
${ }^{7}$ Sugianto (Hakim Pengadilan Industrial pada Pengadilan Negeri Semarang), Wawancara, 18 Januari 2018.
} 
Mengenai sepakat mereka yang mengikatkan dirinya, antara PT. Virgo Makmur Perkasa dengan 4 orang pekerjanya telah sepakat untuk melakukan suatu perjanjian.

Untuk syarat kecakapan membuat suatu perikatan, unsur ini telah dipenuhi oleh kedua belah pihak. Sesuai dengan ketentuan dalam Pasal 1329 KUH Perdata yang menyebutkan bahwa setiap orang yang cakap berwenang untuk membuat perikatan, pengusaha dan 4 orang pekerja PT. Virgo Makmur Perkasa yakni Defri Oktaverian, Tri Saputra, Yosep Saputra, Darul Kodni dianggap cakap karena tidak melanggar ketentuan dalam Pasal 1330 KUH Perdata.

Unsur suatu hal tertentu sebagai salah satu syarat sahnya suatu perjanjian juga terpenuhi karena antara PT. Virgo Makmur Perkasa dengan para pekerjanya membuat suatu perjanjian pekerjaan pengadaan pompa air di wilayah pertambangan batu bara milik PT. Bukit Asam secara lisan.

Unsur sebab yang halal sebagai syarat sahnya suatu perjanjian yang dibuat tidak boleh bertentangan dengan ketertiban umum, kesusilaan, dan peraturan perundang-undangan yang berlaku. Hal ini terbukti karena pekerjaan yang diperjanjikan antara PT. Virgo Makmur Perkasa dengan para pekerjanya tidak bertentangan dengan ketertiban umum, kesusilaan, dan peraturan perundang-undangan yang berlaku.

Jadi, dengan terpenuhinya unsur-unsur tersebut, maka berdasarkan KUH Perdata antara PT. Virgo Makmur Perkasa dengan 4 pekerjanya ada suatu perjanjian kerja karena syarat sahnya suatu perjanjian telah terpenuhi.

\section{Berdasarkan Undang-Undang Nomor 13 Tahun 2003 tentang Ketenagakerjaan}

Pada Pasal 1 angka (15) Undang-Undang Nomor 13 Tahun 2003 tentang Ketenagakerjaan diatur mengenai hubungan kerja, yakni hubungan antara pengusaha dengan pekerja/ buruh berdasarkan perjanjian kerja, yang mempunyai unsur pekerjaan, upah, dan perintah. Pekerjaan yang dilakukan antara PT. Virgo Makmur Perkasa dengan para pekerjanya adalah pengadaan pompa air di pertambangan batu bara milik PT. Bukit Asam dan mereka mendapatkan gaji Rp. 1.630.000/ bulannya, maka perbuatan hukum tersebut dapat disimpulkan telah memenuhi unsur-unsur perjanjian kerja.

Pasal 52 Undang-Undang Ketenagakerjaan menyebutkan perjanjian kerja dibuat harus berdasarkan kesepakatan kedua belah pihak, cakap melakukan perbuatan hukum, ada pekerjaan yang diperjanjikan, dan pekerjaan yang diperjanjikan tersebut tidak bertentangan dengan 
ketertiban umum, kesusilaan, dan peraturan perundang-undangan yang berlaku. Unsur-unsur ini pada perjanjian kerja antara PT. Virgo Makmur Perkasa dengan para pekerjanya telah terpenuhi.

Terhadap ketentuan Pasal 57 ayat (1) Undang-Undang Ketenagakerjaan menyebutkan bahwa PKWT harus dibuat secara tertulis serta menggunakan bahasa Indonesia dan huruf latin. Pasal 57 ayat (2) Undang-Undang Ketenagakerjaan mengatur PKWT yang dibuat tidak tertulis bertentangan dengan ketentuan Pasal 57 ayat (1), maka karena PKWT yang dibuat antara PT. Virgo Makmur Perkasa dengan 4 orang pekerjanya secara lisan, hal ini bertentangan dengan Pasal 57 ayat (1) dan demi hukum harus dinyatakan sebagai PKWTT.

Pasal 59 ayat (1) Undang-Undang Ketenagakerjaan juga mengatur mengenai PKWT, yakni PKWT hanya dapat dibuat untuk pekerjaan yang sekali selesai/ sementara sifatnya, pekerjaan yang diperkirakan penyelesaiannya dalam waktu yang tidak terlalu lama dan paling lama 3 (tiga) tahun, pekerjaan yang bersifat musiman, dan pekerjaan yang berhubungan dengan produk baru, kegiatan baru, atau produk tambahan yang masih dalam percobaan atau penjajakan. Pada Pasal 59 ayat (2), PKWT tidak dapat diadakan untuk pekerjaan yang bersifat tetap. Pada kasus yang terjadi antara PT. Virgo Makmur Perkasa dengan para pekerjanya, pekerjaan yang diperjanjikan bertentangan dengan Pasal 59 ayat (1) dan ayat (2) karena pengadaan pompa air pada pertambangan batu bara adalah terus menerus dan bersifat tetap. Maka, PKWT yang telah diperjanjikan demi hukum menjadi PKWTT dan sebagai konsekuensi hukum dari batalnya PKWT mereka, sejak pertama kali mereka dipekerjakan adalah berstatus pekerja tetap.

Selain menuntut PKWT yang demi hukum menjadi PKWTT, para pekerja PT. Virgo Makmur Perkasa juga menuntut agar Majelis Hakim memberikan putusan sela. Para pekerja meminta majelis hakim untuk menyatakan perbuatan PT. Virgo Makmur Perkasa yang secara nyata tidak melaksanakan kewajiban membayar upah beserta hak-hak lainnya yang biasa diterima para pekerja selama skorsing terhitung sejak bulan Januari 2014 sampai dengan bulan November 2014 adalah perbuatan melanggar hukum, namun hakim menolak memberikan putusan sela.

Tuntutan putusan sela tidak dikabulkan hakim karena pada pertimbangan hakim, menurut kebiasaan dalam praktek peradilan, pada PKWT yang diputus menjadi PKWTT, pengusaha wajib membayar uang pesangon namun tanpa upah proses. Padahal, Pasal 155 ayat (2) UndangUndang Ketenagakerjaan mengatur "Selama putusan lembaga penyelesaian perselisihan hubungan industrial belum ditetapkan, baik pengusaha maupun pekerja/ buruh harus tetap 
melaksanakan segala kewajibannya" dan Pasal 155 mengatur "Pengusaha dapat melakukan penyimpangan terhadap ketentuan sebagaimana dimaksud dalam ayat (2) berupa tindakan skorsing kepada pekerja/ buruh yang sedang dalam proses pemutusan hubungan kerja dengan tetap wajib membayar upah beserta hak-hak lainnya yang biasa diterima pekerja/ buruh". Pengaturan mengenai hal ini juga dikuatkan dengan adanya putusan Mahkamah Konstitusi No 37/PUU-IX/2011 tentang Permohonan Pengujian Undang-Undang Nomor 13 Tahun 2003 tentang Ketenagakerjaan terhadap UUD NRI 1945, yang amar putusannya menyatakan: "Frasa 'belum ditetapkan' dalam Pasal 155 ayat (2) Undang-Undang Nomor 13 Tahun 2003 tentang Ketenagakerjaan bertentangan dengan UUD NRI 1945 dan tidak mempunyai kekuatan hukum mengikat sepanjang tidak dimaknai 'belum berkekuatan hukum tetap'”. Hal ini berarti para pihak dalam hubungan industrial (baik pengusaha maupun pekerja/ buruh) harus tetap melaksanakan hak serta kewajiban masing-masing seakan belum efektif terjadi PHK. Dengan demikian maka putusan MK tersebut harusnya menjadi dasar acuan tentang pemberian upah skorsing/ upah proses kepada para penggugat, yakni harus dibayarkan tergugat hingga perkara tersebut memperoleh kekuatan hukum tetap.

Pada Pasal 156 Undang-Undang Ketenagakerjaan mengatur dalam hal terjadi pemutusan hubungan kerja, pengusaha diwajibkan membayar uang pesangon dan/ atau uang penghargaan masa kerja dan uang penggantian hak yang seharusnya diterima. Dalam hal ini, hakim memutus PT. Virgo Makmur Perkasa untuk membayarkan uang pengakhiran hubungan kerja yakni uang pesangon dan uang penggantian hak. Hakim tidak memutus uang penghargaan masa kerja karena masa kerja para pekerja PT. Virgo Makmur Perkasa belum ada 3 tahun, dan syarat untuk mendapatkan uang penghargaan masa kerja yang diatur Pasal 156 ayat (3) adalah minimal 3 tahun masa kerja. ${ }^{8}$ Maka, berdasarkan fakta-fakta hukum dalam persidangan di atas, penulis berpendapat bahwa perkara yang telah diputus oleh Mahkamah Agung Nomor 501 K/Pdt.SusPHI/2016 tidak sesuai dengan Undang-Undang Nomor 3 Tahun 2013 tentang Ketenagakerjaan, terlebih mengenai upah skorsing yang seharusnya diputus oleh hakim.

\footnotetext{
${ }^{8}$ Sugianto (Hakim Pengadilan Industrial pada Pengadilan Negeri Semarang), Wawancara, 18 Januari 2018.
} 


\section{Berdasarkan Undang-Undang Nomor 2 Tahun 2004 tentang Penyelesaian Perselisihan Hubungan Industrial}

Sebagaimana diatur dalam Undang-Undang Nomor 2 Tahun 2004 tentang Penyelesaian Perselisihan Hubungan Industrial dalam Pasal 3 ayat (1) yang menyebutkan bahwa penyelesaian perselisihan diwajibkan menempuh upaya perundingan bipartit terlebih dahulu. Pada kasus yang terjadi antara PT. Virgo Makmur Perkasa dengan 4 orang pekerjanya, proses penyelesaian diawali tahap bipartit terlebih dahulu, kemudian dilanjutkan dengan penyelesaian tripartit yakni mediasi. Karena perundingan bipartit dan mediasi tidak mencapai kemufakatan, maka permasalahan tersebut dilanjutkan pada Pengadilan Hubungan Industrial.

Pada Pasal 13 ayat (2) Undang-Undang PPHI diatur jika tidak tercapai kemufakatan penyelesaian melalui mediasi, maka mediator mengeluarkan anjuran tertulis. Hal ini telah dilakukan oleh mediator pada Dinas Tenaga Kerja dan Transmigrasi Kabupaten Muara Enim dengan mengeluarkan risalah penyelesaian dan risalah tersebut dilampirkan pada gugatan ke PHI PN Palembang.

Tuntutan para penggugat yang menuntut upah skorsing tidak dikabulkan majelis hakim karena pada pertimbangan hakim, menurut kebiasaan dalam praktek peradilan, pada PKWT yang diputus menjadi PKWTT, pengusaha wajib membayar uang pesangon namun tanpa upah proses. Padahal pada dasarnya, hak pekerja/ buruh atas upah timbul pada saat terjadi hubungan kerja antara pekerja/ buruh dengan pengusaha dan berakhir pada saat putusnya hubungan kerja. Pekerja dan pengusaha harus tetap menjalankan kewajiban masing-masing seakan belum efektif terjadi PHK sampai adanya penetapan Lembaga Penyelesaian Perselisihan Industrial yang berkekuatan hukum tetap. Maka, pekerja yang dikenakan skorsing oleh pengusaha seharusnya tetap berhak menerima upah.

Jadi, menurut penulis, proses penyelesaian perselisihan hubungan industrial dalam kasus ini kurang sesuai dengan proses penyelesaian perselisihan hubungan industrial pada ketentuan Undang-Undang Nomor 2 Tahun 2004 tentang Penyelesaian Perselisihan Hubungan Industrial, karena seharusnya majelis hakim menyatakan para penggugat berhak mendapatkan upah skorsing dalam putusannya. 


\section{Berdasarkan Keputusan Menteri Tenaga Kerja dan Transmigrasi Nomor 100/MEN/VI/2004 tentang Ketentuan Pelaksanaan Perjanjian Kerja Waktu Tertentu}

Yang termasuk lingkup dalam perjanjian waktu tidak tertentu adalah pekerjaan yang sifatnya sekali selesai/ sementara sifatnya, pekerjaan yang diperkirakan penyelesaiannya tidak terlalu lama dan paling lama 3 tahun, pekerjaan yang bersifat musiman, dan pekerjaan yang berhubungan dengan produk baru/ kegiatan baru/ produk tambahan yang masih dalam percobaan atau penjajakan. Dalam kasus yang terjadi antara PT. Virgo Makmur Perkasa dan 4 pekerjanya, para pekerja tersebut dipekerjakan pada pekerjaan jasa pengadaan pompa air di lokasi penambangan batu bara di Tanjung Enim, Sumatera Selatan, maka hal ini tidak memenuhi syarat perjanjian kerja waktu tertentu sebagaimana dimaksud Pasal 3, Pasal 4, dan Pasal 5 Kepmenakertrans Nomor 100/MEN/VI/2004 tentang Ketentuan Pelaksanaan Perjanjian Kerja Waktu Tertentu karena sifat, jenis, dan kegiatan pekerjaan jasa pengadaan pompa pada aktivitas penambangan batu bara di perusahaan milik PT. Bukit Asam (turut tergugat) adalah terus menerus dan bersifat tetap, sehingga demi hukum hubungan kerja dimaksud menjadi PKWTT.

Selain itu, pada Pasal 15 Kepmenakertrans Nomor 100/MEN/VI/2004 juga mengatur PKWT dapat berubah menjadi PKWTT apabila PKWT tidak dibuat dalam bahasa Indonesia dan huruf latin.

Jadi, menurut penulis, putusan hakim Pengadilan Hubungan Industrial dan hakim Mahkamah Agung telah sesuai dengan Kepmenakertrans Nomor 100/MEN/VI/2004 tentang Ketentuan Pelaksanaan Perjanjian Kerja Waktu Tertentu.

\section{Kesimpulan}

Berdasarkan dari uraian yang telah dikemukakan dalam pembahasan tersebut di atas, maka dapat disimpulkan sebagai berikut:

1. Perjanjian kerja tidak harus dilakukan secara tertulis. Akan tetapi, harus dilihat terlebih dahulu perjanjian kerja tersebut termasuk Perjanjian Kerja Waktu Tertentu (PKWT) atau Perjanjian Kerja Waktu Tidak Tertentu (PKWTT) karena PKWT harus dilakukan secara tertulis serta harus menggunakan bahasa Indonesia dan huruf latin. Jika ternyata PKWT tersebut dibuat secara lisan, maka demi hukum perjanjian kerja tersebut menjadi PKWTT.

2. Putusan hakim kurang adil untuk kedua belah pihak yang berperkara karena tergugat tidak dihukum untuk membayar upah skorsing (upah proses) dengan menitikberatkan pada 
pertimbangan PKWT tidak tertulis sehingga demi hukum menjadi PKWTT. Selain itu majelis hakim juga berpendapat sesuai kebiasaan dalam praktek peradilan dalam memutus PKWT menjadi PKWTT adalah dengan tanpa memutus upah proses.

3. Tuntutan upah proses yang tidak dikabulkan oleh hakim bertentangan dengan peraturan perundang-undangan tentang ketenagakerjaan dan tentang penyelesaian perselisihan hubungan industrial karena undang-undang memerintahkan pekerja dan pengusaha tetap menjalankan kewajibannya sampai ada penetapan Lembaga Penyelesaian Perselisihan Industrial, termasuk kewajiban pengusaha membayarkan upah skorsing (upah proses). Putusan Mahkamah Konstitusi No 37/PUU-IX/2011 tentang Permohonan Pengujian Undang-Undang Nomor 13 Tahun 2003 tentang Ketenagakerjaan terhadap UUD NRI 1945 memerintahkan hakim harus menghitung upah proses sampai dengan putusan tersebut berkekuatan hukum tetap. Maka Putusan Mahkamah Agung Nomor 501 K/Pdt.Sus-PHI/2016 kurang sesuai dengan peraturan perundang-undangan yang berlaku di Indonesia.

Pemutusan hubungan kerja didasarkan dengan adanya suatu perjanjian diantara kedua belah pihak. Antara pengusaha dan pekerja/ buruh, perjanjian yang dibuat tersebut sebaiknya dibuat secara tertulis, bukan secara lisan. Meskipun peraturan perundang-undangan tidak memberikan larangan dengan adanya suatu perjanjian yang dibuat secara lisan, namun jika perjanjian dibuat secara lisan hal itu dapat menimbulkan suatu permasalahan jika terjadi suatu perselisihan di kemudian hari. Pemerintah juga harus mengatur mengenai adanya sanksi yang tegas terhadap pengusaha yang melanggar mengenai Perjanjian Kerja Waktu Tertentu sehingga dapat memberikan perlindungan bagi pekerja/ buruh.

\section{Daftar Pustaka}

Khakim, Abdul. 2014. Dasar-Dasar Hukum Ketenagakerjaan Indonesia. Bandung : PT. Citra Aditya Bakti.

Nazir, Mohammad. 2003. Metode Penelitian. Jakarta : Ghalia Indonesia.

Soekanto, Soerjono dan Sri Mamudji. 2004. Penelitian Hukum Normatif Suatu Tinjauan Singkat. Jakarta : PT Raja Grafindo Persada.

Soemitro, Ronny Hanitjo. 1994. Metode Penelitian Hukum. Jakarta : Ghalia Indonesia.

Pancasila

Undang-Undang Dasar Tahun 1945

Undang-Undang Nomor 2 Tahun 2004 tentang Penyelesaian Perselisihan Hubungan Industrial Undang-Undang Nomor 13 Tahun 2003 tentang Ketenagakerjaan 
Keputusan Menteri Tenaga Kerja dan Transmigrasi Nomor 100/MEN/VI/2004 tentang Ketentuan Pelaksanaan Perjanjian Kerja Waktu Tertentu.

Putusan Mahkamah Agung Nomor Nomor 501 K/Pdt.Sus-PHI/2016;

Putusan Mahkamah Agung Nomor 404 K/Pdt.Sus-PHI/2014;

Putusan Pengadilan Hubungan Industrial pada Pengadilan Negeri Palembang Nomor 28/Pdt.SusPHI/2014/PN.Plg;

Putusan Pengadilan Hubungan Industrial pada Pengadilan Negeri Semarang Nomor 44/G/2013/PHI.Smg.

Sugianto (Hakim Pengadilan Industrial pada Pengadilan Negeri Semarang), Wawancara, 18 Januari 2018.

Tri Jata Ayu Pramesti, Bolehkah Memotong Upah Pekerja yang di-Skorsing?, http://www.hukumonline.com/klinik/detail/1t51480c37790ca/bolehkah-memotong-upah-pekerjayang-di-skorsing, diakses pada tanggal 19 Januari 2018.

Konfederasi Serikat Buruh Sejahtera Indonesia, Putusan Sela Pengadilan Hubungan Industrial, http://www.ksbsi.org/index.php/baca/lengkap/154, diakses pada tanggal 19 Januari 2018. 